\title{
International Trade, Do Institutions Matter? Evidence from Regional Studies
}

\author{
Paul Ojeaga ${ }^{*}$, Emmanuel George ${ }^{2}$, Phillip 0. Alege ${ }^{3}$, Adeyemi Ogundipe ${ }^{3}$ \\ ${ }^{1}$ Bergamo University, Bergamo, Italy \\ ${ }^{2}$ Olabisi Onabanjo University, Ago Iwoye, Ogun, Nigeria \\ ${ }^{3}$ Covenant University, Ota, Nigeria \\ Email: "paul.ojeaga@unibg.it
}

Received 28 March 2014; revised 16 May 2014; accepted 2 July 2014

Copyright (C) 2014 by authors and Scientific Research Publishing Inc.

This work is licensed under the Creative Commons Attribution International License (CC BY). http://creativecommons.org/licenses/by/4.0/

(c) (i) Open Access

\begin{abstract}
The study investigates the relationship between trade and institutions across regions using panel data for seven regions for the period 1980 to 2010 (31 years) and general method of moment estimation method (GMM). Consistent with past literature, institutions were found to have a significant effect on trade. Different measures that capture institutions were used, domestic and international institutions were found to be significantly promoting exports across regions and it was concluded that institutions mattered reasonably in the trade promotion discussion. Domestic institutions were protectionist in nature since they increased tariffs on imported goods, while international institutions were probably reducing regional tariffs.
\end{abstract}

\section{Keywords}

Exports, International Trade, Institutions, Market Size and Transaction Cost

\section{Introduction}

Few papers if any have tried to examine the relationship between exports and institutions by considering both domestic and international institutions contributions to exports as we do in this study. The role of institutions on exports promotion has generated a lot of heated debate among scholars, but the link between trade and institutions remains unclear. While domestic institutions can facilitate legal right enforcement and social policy implementation which could improve infrastructure and the domestic business environment, international institutions can provide access to foreign capital to boost trade capabilities as well as facilitate regional trade alliance through international agencies such as the World Trade Organization (WTO).

"Corresponding author.

How to cite this paper: Ojeaga, P., George, E., Alege, P.O. and Ogundipe, A. (2014) International Trade, Do Institutions Matter? Evidence from Regional Studies. Theoretical Economics Letters, 4, 584-597.

http://dx.doi.org/10.4236/tel.2014.47074 
Regions can benefit enormously from international trade, by strategically positioning themselves to exploit the advantages arising from international trade in commodities. Export oriented growth and trading in the global market has the capacity to alleviate poverty and support entrepreneurship in many developing countries, while it also has the tendency to drive growth, promote learning and transfer of technology in many cooperating developed economies. Institutions on the other hand can play a vital role in reducing the overall cost of trade across regions since reducing the cost of transportation to local and foreign markets can be a strong incentive for exporters. Other ways through which institutions can affect trade is through the development of regional market size which can improve export potential, reduce regional tariffs and develop infrastructure that can considerably reduce transaction cost of trade across regions

There are many ways through which trade is also likely to contribute to the overall growth and development of a country. Exports can for instance serve as a source of income to a country thereby boosting the exporting countries GDP. While relations accruing from trade, can help in the facilitation of foreign direct investment and transfer of new technology. Output productivity has been found to vary differently with regions [1]. Regional climatic differences often mean, agricultural products and jobs sectors are different across regional divide. The nature of production in sectors often affects the type of exports from regions, for instance the services sectors accounts for a greater percentage of labor market participation in developed countries (particularly Europe and North-America), while most developing countries in Africa and Latin America often depend more on agriculture, exports from Latin America are mainly in basic food items, consumer goods and building materials while the developed economies are likely to export finished goods such as machinery, automobiles etc [1].

Trade across regions today is currently been facilitated by various regional trade alliances, for instance the North American economy is divided into three major blocks which include the North America Free Trade Association (NAFTA), the Caribbean Community and Common Market (CARICOM) and the Central American Common Market (CACM) which helps the regional trade facilitation process. Canada and the United States have already concluded one of the Worlds bilateral trade treaties that have resulted in the total elimination of tariffs in goods and services across their borders. Mexico's recent qualification for tariff free trade with the United States through the NAFTA agreement has also improved trade among the three major North America countries by over $24 \%$ since 2010 [2].

In 2012 the European Union economy had a combined GDP of 16.07 trillion dollars [3]. Credit Suisse Global Wealth report 2012, also states that the EU has the highest net wealth in the World and currently consist of 33\% of the total global net wealth. It is made up of 28 countries with a single common market which makes up the European Economic Community consisting of three non member countries which are Norway, Switzerland and Liechtenstein [4].

Australia also has the fifth highest per capita GDP and the twelfth largest economy in the world. Owing to a sustained balance in exports of manufactured products and commodities, Australia is the only OECD country not to have experienced a recession during the 2008/2009 global economic prices. However subsections of the Australian economy have persistently been affected by global financial crises of 2007, particularly through its non mining sub-regions, whose economies have entered into recession despite its national GDP growth of 3.5\%. Most of Australia's trade is with Japan and China, with the United States and New Zealand been a distant third and fourth.

According to [5], the African economy is endowed with enormous natural resources and has the capability of feeding and sustaining its population. While Africa continues to export primary commodities, trade among African countries is often lacking. In 2005 Africa's economy grew by 5\% [6]. However, the sub-Saharan region of Africa has been the least successful in poverty reduction, with more that $50 \%$ of the population, living below the poverty line [6]. [7], also state that nearly $52 \%$ of the children in sub-Saharan Africa were enrolled in primary schools this was the lowest compared to other continents particularly Europe and Australia. The obvious implication is that, with a considerable percentage of unskilled manpower, its exports are likely to be considerably in primary goods meaning that Africa is not likely to take advantage of the benefits of product differentiation due to its poor technological capabilities. Other regions such as Latin America, the Middle-east and South East Asia are also heavily reliant on agriculture and mineral exports. Tourism has also thrived in South East Asia, while countries like China and Japan, export a considerable amount of manufactured goods [4].

This paper investigates the relationship between trade and institutions using sample data from seven regions which include Sub Saharan Africa, European Union, North America, Latin America, Australia, Middle-East and North Africa and South East Asia Pacific from 1980 to 2010, 31 years. The study utilizes different measures of institutions obtained from World Development Indicator (WDI) data to study the effect of institutions on export 
promotion across regions. Two different set of institutional quality index were constructed for domestic and international measures of institutions respectively, we created these indexes using principal component analysis (PCA) which uses Eigen-values matrix to generate variables from a set of closely related variables as in [8] [9] and regression components coefficients (RCC) obtained from regression residuals see [10] for further discussion. The method of estimation used is the general method of moment (GMM). The rest of the study consist of scope and objectives of the study, review of literature, the stylized facts on trade and institutions, the theory and methodology, data and sources, empirical analysis and results and finally discussion and concluding section.

\section{Scope and Objectives of Study}

This paper reviews factors that affect international trade across regions and presents empirical evidence, on how institutions affect regional trade, by studying the effect of institutions on exports. The objectives of the study include:

a) To determine if institutions matter in the promotion of international trade in exports across regions?

b) To determine institutional effectiveness in improving or reducing access to domestic and foreign destination markets?

c) To examine the extent to which institutions develop regional markets?

d) Finally to determine the extent to which institutions affect tariffs in regions?

\section{Review of Literature}

Few regional studies have undertaken the task of studying the impact of institutions on trade from a regional point of view. Studies by [11] [12] argue that weak institutions are often responsible for slower growth. Others have posited that weak institutions are many a time responsible for lower factor productivity and lower per capita income see [13]-[15] using instrumental variable estimation to account for the endogeneity.

The debate on how exactly institutions can affect the overall economy of a country remains vague, since many studies have not till date arrived, at some specific channels through institutions impact growth. A host of variables have been found to be adversely affected by institutions, some include foreign direct investment [16], capital accumulation, total investment and other specific forms of public investments etc. Till date not many papers have also thoroughly dealt with the dynamics between trade in commodities and institutions, [17] observed the risk of predation due to contract default and states that imperfect enforcement of contract has a negative effect on foreign trade flow.

However, other in-depth studies such as [18] find that institutional quality is highly correlated with trade, this made them to be primarily concerned with long term decadence growth, which they attributed to be affected by trade oriented growth and institutions. They also attributed rising income and falling poverty to perceived liberalization expansion in countries arguing that such expansion are in fact responsible for trade growth and economic growth on the long run.

[19] studies liberalization regimes and find that trade growth is strongly related to economic growth and investment. Although the paper, by [20], does not find a direct relation between trade and income, they find that there exist a complex relationship between institutions, trade and growth in a host of countries. They also argue that institutions have a direct effect on incomes, meaning that trade has an indirect effect on incomes through institutions.

Institutions, on the other hand have the tendency to promote integration, while integration is likely to affect institutional quality in a positive manner. Other papers such as [21] have studied the dynamics of trade and growth and stress that labour and business regulation are also quite important. [22], provide evidence from panel studies that a broad domestic mix of policy, institutions and infrastructure plays a significant role in moderating trade impact on growth in countries.

Development agencies on the other hand have focused extensively on growth and trade facilitation processes, development assistance, regional integration and offered strong recommendation for sustained institutional development, thereby arguing that development is interlinked with the political economic reforms, institutional development, past colonial ties and history, development assistance as well as North-South trade partnerships.

Finally, [23] study intensively, the impact of economic freedom on US consumer exports and imports and find that institutional quality of partner countries has a positive effect on US exports to such countries. Since in- 
ternational trade is not likely to be homogenous, developed countries that exports finished and differential goods will continue to have a strategic trade advantage over countries that export only primary goods.

\subsection{Stylized Facts on Regional Trade and Institutions}

International trade in goods has not returned to the rapid growth rate of the years preceding the crisis (see Figure 1 \& Figure 2). On the contrary, it decelerated further in 2012, and while the outlook for world trade remains uncertain, the first signs in 2013 do not point to an expansion. After a sharp fall in 2008-2009 and a quick recovery in 2010, the volume of trade in goods grew by only 5.3 per cent in 2011 and by 1.7 per cent in 2012. This slower rate of expansion occurred in developed, developing and transition economies alike, see Table 1 [24].

Sluggish economic activity in developed economies accounted for most of the slow down in international trade (See Table 1). In 2012, european imports of goods shrank by almost 3 percent in volume and by 5 percent in value. Extremely weak intra-european trade was responsible for almost 90 percent of the decline in european exports in 2012. Likewise, Japan's exports have not yet recovered from their sharp fall caused by the earthquake of 2011, while the volume of imports has continued to grow at a moderate pace. Also, among the developed economies, only the United states maintained a positive growth rates in its international trade, although this appears to be slowing down in 2013. Trade in general (aggregate exports and imports) also decelerated considerably in developing and transition economies in 2007 due to the global recession. However sluggish increases are noticeable in 2012, in most developing regions. The sole exception was Africa, where exports recovered in countries previously affected by civil conflict. Export growth declined to 4 per cent in the developing countries as a whole see [5]. This slowdown included Asian countries that had previously played a major role in boosting international trade.
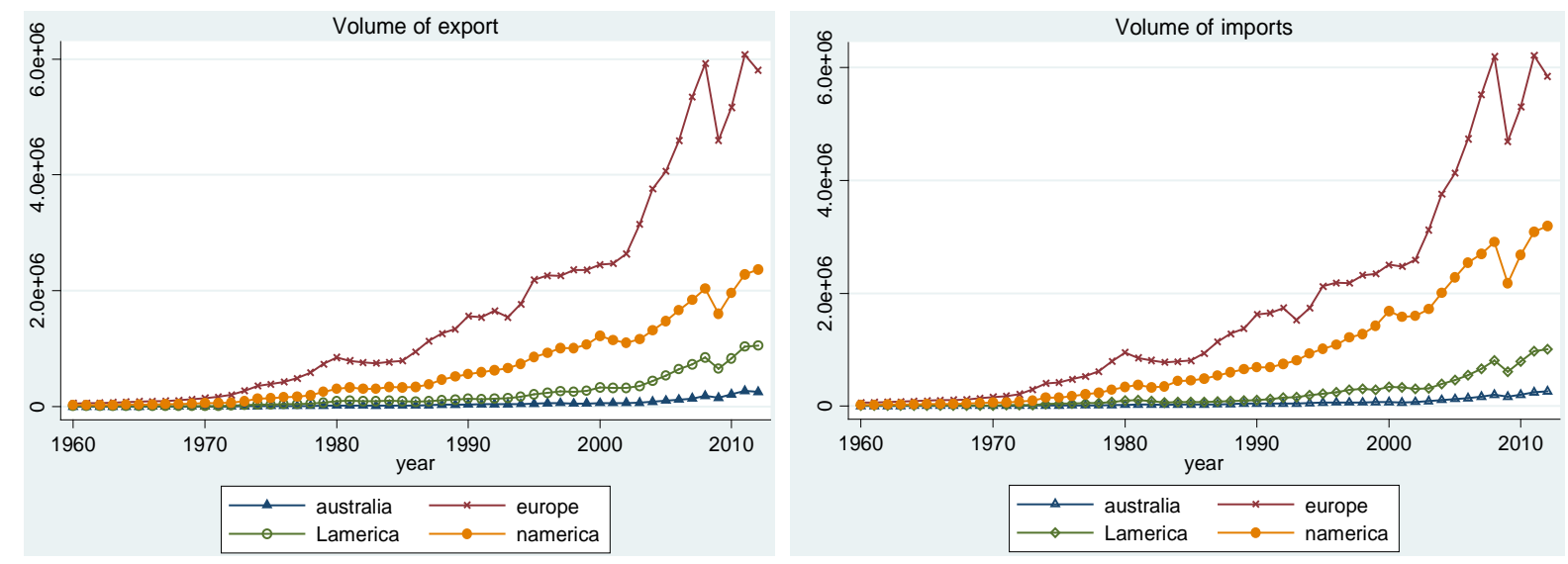

Figure 1. Regional trade structure by regions (1960-2010).
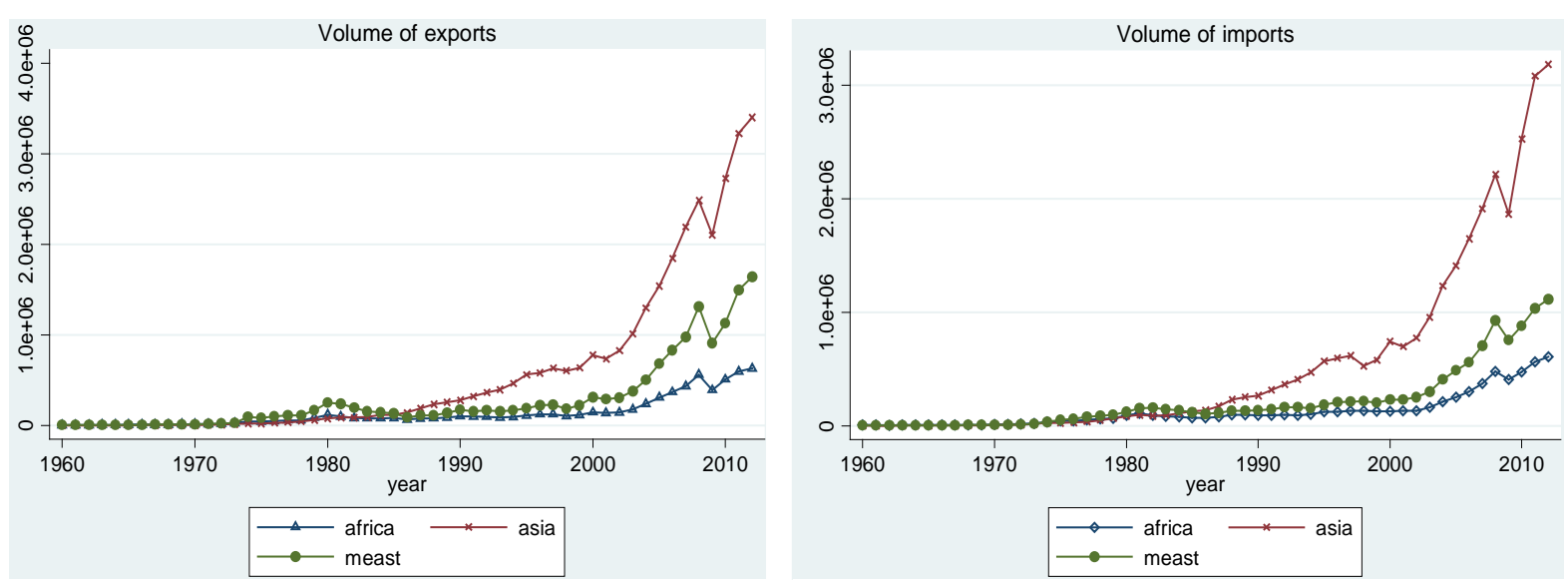

Figure 2. Regional trade structure by regions (1960-2010). 
Table 1. Trade, institutions and economic growth trends.

\begin{tabular}{cccccccccccccccc}
\hline & $\begin{array}{c}\text { Regional share } \\
\text { of world non-oil } \\
\text { export }\end{array}$ & \multicolumn{2}{c}{$\begin{array}{c}\text { Per capita } \\
\text { income }\end{array}$} & $\begin{array}{c}\text { GDP growth } \\
\text { rates }\end{array}$ & $\begin{array}{c}\text { Share in world } \\
\text { population }\end{array}$ & $\begin{array}{c}\text { Strength of } \\
\text { legal right }\end{array}$ & $\begin{array}{c}\text { No. of days } \\
\text { to execute } \\
\text { contract }\end{array}$ & $\begin{array}{c}\text { No. of } \\
\text { major } \\
\text { countries }\end{array}$ \\
\hline Region/year & 2000 & 2010 & 2000 & 2010 & 2000 & 2010 & 2000 & 2010 & 2000 & 2010 & 2000 & 2010 \\
Australia & 0.32 & 0.27 & 33,379 & 38,837 & 2.00 & 1.91 & 0.31 & 0.32 & 9 & 9 & 395 & 395 & 1 \\
Africa & 0.67 & 0.87 & 965 & 1257 & 3.44 & 4.85 & 13.23 & 14.81 & 4.6 & 4.65 & 625 & 651 & 61 \\
Asia & 24.14 & 35.41 & 1499 & 2577 & 6.76 & 8.70 & 57.05 & 56.97 & 4.7 & 6.1 & 476 & 493 & 51 \\
Europe & 39.91 & 38.51 & 25,929 & 28,669 & 3.92 & 2.13 & 7.89 & 7.28 & 6.7 & 7.0 & 568 & 549 & 27 \\
Latin America & 4.15 & 3.53 & 4804 & 5843 & 4.48 & 6.02 & 7.58 & 7.59 & 3.9 & 5.4 & 710 & 711 & 26 \\
Middle east & 1.30 & 2.50 & 3899 & 4998 & 5.39 & 6.33 & 6.02 & 6.47 & 3.4 & 3.5 & 661 & 670 & 17 \\
North America & 20.54 & 12.71 & 31,198 & 32,916 & 4.41 & 2.61 & 6.81 & 7.00 & 8 & 8 & 435 & 435 & 3 \\
\hline
\end{tabular}

Source: Authors' compilation. Note: The table above depicts regional share in world non oil exports, GDP growth, population increases and improvements in institutional quality as shown by regional strength of legal rights and time to execute contracts, compiled by the authors from data used in this study obtained from world development indicators of the World Bank and other sources.

Considerably in developing and transition economies. Both exports and imports grew sluggishly in 2012 and the first months of 2013, in most developing regions. The sole exception was Africa, where exports recovered in countries previously affected by civil conflict. Export growth declined to 4 per cent in the developing countries as a whole. This slowdown included Asian countries that had previously played a major role in boosting international trade.

The crisis of 2008-2009 has altered trade patterns in both developed and developing countries. Imports by all developed regions remain below their pre-crisis level, and only the United States has managed to increase its exports to a higher level than their previous peak of August 2008 (see Figure 1). On the other hand, exports from the group of emerging market economies were 22 per cent above their pre-crisis peaks, while the corresponding figure for their imports was 26 per cent higher (see Figures 2-4). However, the pace of growth of trade of these economies has slowed down significantly: during the pre-crisis years, between 2002 and 2007, their export volume grew at an average annual rate of 11.3 per cent, but fell to only 3.5 per cent between January 2010 and April 2013. Growth in the volume of their imports also slowed down from 12.4 per cent to 5.5 per cent over the same period [25].

Trade growth also decelerated considerably in developing and transition economies in 2012, though the figures remained positive for most countries. In the transition economies, the rate of growth of the volume of exports was 1 per cent in 2012, down from 4.2 per cent in 2011, and that of imports was 3.9 per cent in 2012, down from 15.7 per cent in 2011. Likewise, in developing countries the rate of growth of exports fell from 6 per cent in 2011 to 3.6 per cent in 2012, and that of imports from 7.4 per cent in 2011 to 4.5 per cent in 2012.

At the sub-regional level, two notable exceptions stand out from this general pattern of developing country trade. The first is the recovery of trade in some North African economies from low levels in 2011, which contributed to higher trade growth in Africa as a whole. The second is the absolute decline in the volume of exports from South Asia, explained mainly by a reduction of oil exports from the Islamic Republic of Iran, though India's export volumes also fell, by 2.5 per cent. This was largely due to the economic slowdown in Europe, which accounts for almost one fifth of India's total exports, as well as weak exports to China.

Inefficient institutions, in contrast, can lead to serious obstacles for trade. [26], for instance, describe how the absence of an efficient legal system hinders interaction between manufacturing firms in a number of African countries and potential foreign importers (see Table 1). It is shown that contractual flexibility is pervasive and that it is a rational response to risk: the riskier the environment, the higher the incidence of contract non-performance, and the higher the probability of renegotiation of a contract. Complete contract breaches and the use of lawyers and courts to enforce the original contract are rare, simply because of the absence of an efficient legal system. Instead, suppliers and clients fulfill their contracts but in a "flexible" way: supplies occasionally arrive late or their quality is different from what was ordered, and clients sometimes pay late. In their dealings with African firms, trading partners are often taken by surprise by contractual delays and calls for contractual 

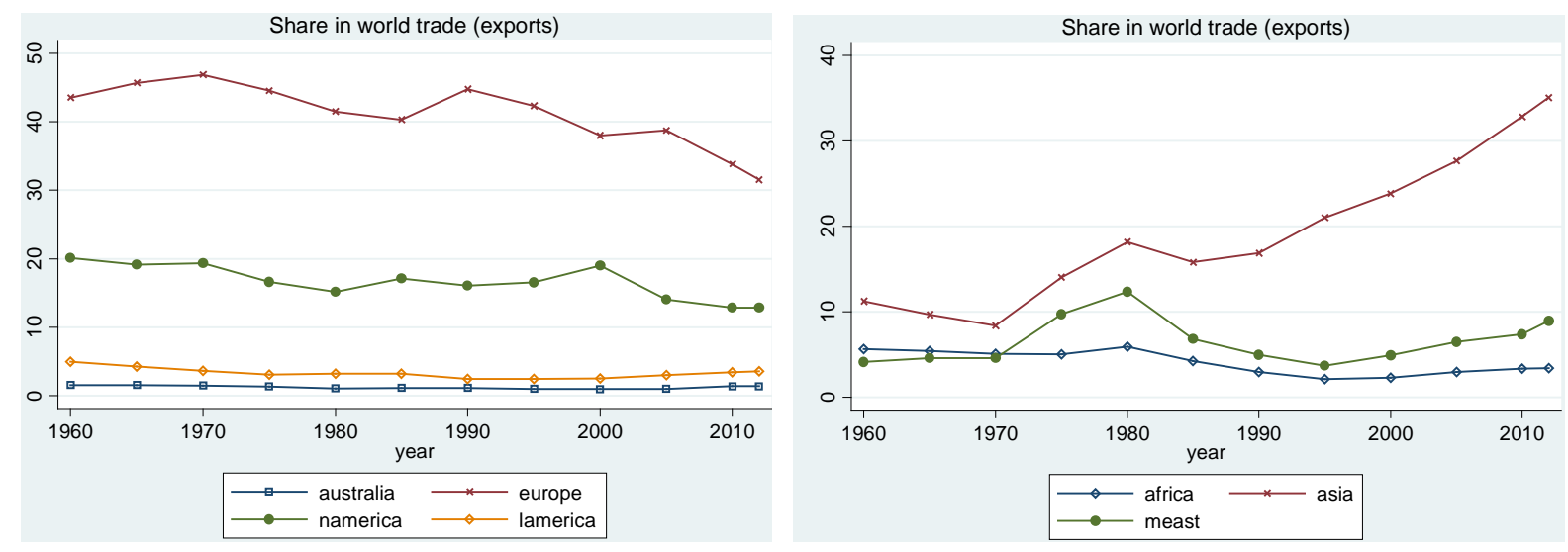

Figure 3. Regional share in world trade (1960-2010).
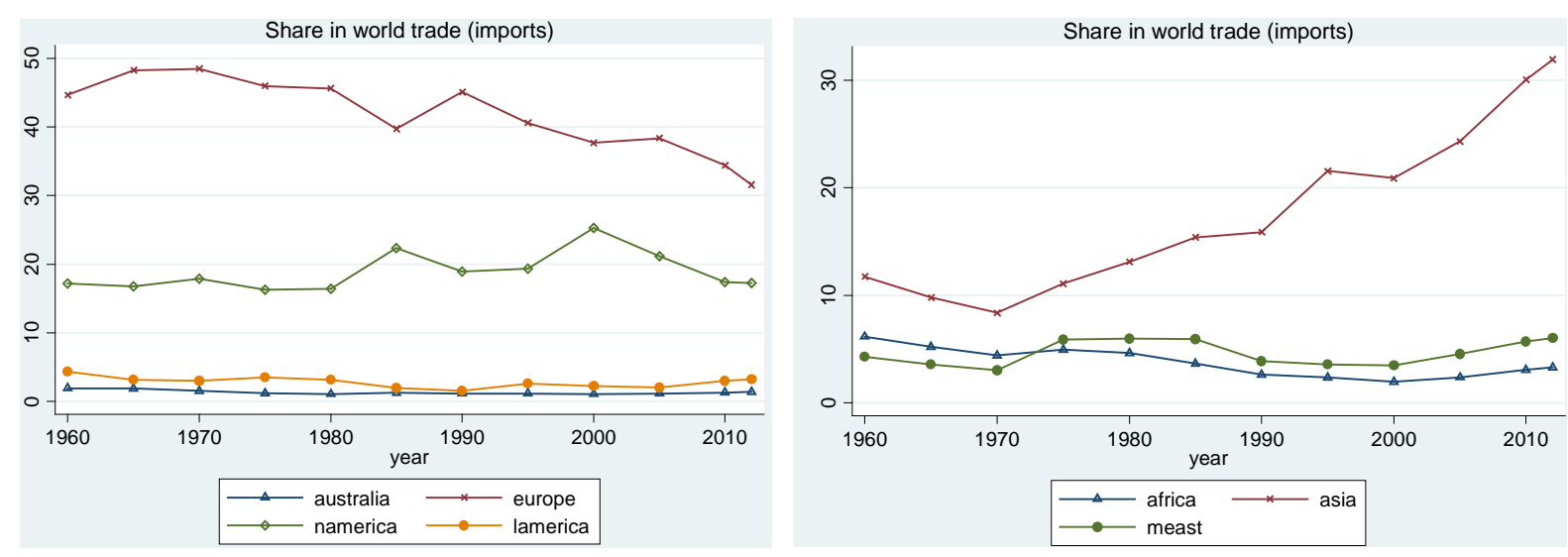

Figure 4. Regional share in world trade (1960-2010).

renegotiation. Those who are used to functioning in a very different environment may find it hard to understand that the somewhat unpredictable behaviour of African firms in such cases is a rational response to an inefficient system [27]. This may explain why foreign firms find it difficult to deal with African partners and why African manufacturers have a hard time breaking into foreign export markets.

Inefficient institutions also represent a cost factor for domestic exporters and thus lower their international competitiveness with negative repercussions on export flows; transaction costs due to inefficient institutions also raise the final consumer price of imported goods with negative repercussions on a country's import flows. Evidences from empirical and theoretical literature suggest that lower institutional quality has a substantially negative effect on trade [28]; likewise, [29] discovered that better quality of formal institutions tends to coincide with more trade and that similarity between trading partners in the quality of their institutions promotes trade.

\subsection{Theory and Methodological Review}

The theory relied on in the study, is one in which the institutional environment will affect exports in regions, past studies, [15] [30], argue that weak institutions are likely to impede growth, making institutions to have strong implication for the private sector of an economy which we extend to include other factors that affect trade. In the case of trade this can happen for two reasons: a) There will be a direct effect of institutions on exporting such that local producers or exporters will receive back their invested revenue in trade plus profits, this will make local producer export more; b) Secondly due to gains accruing from exports as result of good institutions, new producers are likely to want to take to exporting and establish trade partnerships taking advantage of the profits from exports.

The implications of institutions for trade is that if domestic institutions are good in destination markets profits are likely to be greater than zero $(\pi>0)$, while the effectiveness of international institutions on trade will be one 
where good international institutions will stimulate trade through regional market development and promotion causing exporters to have channels and destination markets to export to, making exports to be non zero (therefore exports $x>0$ ). Institutions will now be expressed as a function of both domestic and international institutions, Institutions f(domestic and international institutions).

\subsubsection{The Equations and Model Specification}

Domestic institutions in destination markets will shape exporters belief to export to destination markets and can be expressed as destination countries level of implementation of social infrastructural policy and contract enforcements which we express in terms of legal rights written as; Domestic institutions (DOM INST.) f(social policy implementation (SOCp) and legal rights implementation (LEGALr)) expressed below as:

$$
\text { DOM INST. }=\text { SOCP }+ \text { LEGALr }
$$

International institutions will affect the exporters ability to penetrate foreign markets and will depend on the flow of capital towards boosting international trade capabilities from international multilateral agencies as well as regional trade policy that will drive access to international markets (market access) which is represented by the dummy for membership of world trade organization which we express below as; International institutions (INT. INST.) f(multilateral foreign aid inflow to trade (INT. Ka) and World Trade Organization membership(INT. Ma)) expressed below as:

$$
I N T . I N S T .=I N T . K a+I N T . M a
$$

International trade in commodities will also depend of a host of exogenous factors such as FDI, exchange rates since currency is not homogenous across regions, average tariffs at destinations, destination country market size, and market access which is the cost of transportation to destination markets. This allows us to express the institutional effect as it affects trade both domestically and internationally, which can be expressed as; Institutions f(social policy implementation, legal rights enforcement, inflow of foreign capital to develop trade capabilities and international trade policy) expressed below in Equations (3) and (4) as:

$$
\begin{aligned}
& I N S T k=D O M I N S T .+I N T . I N S T . \\
& I N S T k=(S O C p+L E G A L r)+(I N T . K a+I N T . M a)
\end{aligned}
$$

The model estimated depicts one in which the volume of exports varies either positively or negatively, with trading partnership this will be particularly true since the nature of partnership will depend on institutions. If a trade contract implies a contract where the profit $\pi$ is greater than zero $(\pi>0)$, we can evaluate some probable scenarios and make prepositions based on these as follows: i) How exporters and distributors partnership relationships begin and terminate; ii) Secondly, how at equilibrium such partnership are likely to be formed; iii) How profit maximization goals of distributors and importers can sustain partnership; iv) And finally how the exporter positive gains will maintain trade relationships see Araujo, Mion and Ornelas (2012) for further discussion.

We proffer answers to the theoretical prepositions as follows i) Exporters and distributors partnership relationships begin when the institutional effect on trade makes profit to be greater than 0 we call this condition 1 , thereby instigating trade interaction and trade will terminate when the institutional effect deteriorate to a condition when profits are less than zero we call this condition 0 since the termination of the relation returns to the no trade condition; ii) Secondly, at equilibrium which is also condition 0 such partnership are likely to be formed if there are perceived incentive to be derived from trade such as guarantee of good institutional factors that can enhance the business environment; iii) Profit maximization goals of distributors and importers can sustain partnership if only institutions continue to enhance exporting and profit is higher than zero; iv) Finally the exporter positive gains will maintain trade relationships if there exist sufficient incentive for consumers and there are no alternative markets or substitute products where consumers can minimize cost, since finding such products or markets can also terminate the relationship by reducing exporter's incentive to trade.

Previous study by [31] argue extensively about how, the institutional environment both domestic and international affect home exports, they also expanded the argument in their subsequent paper [32] by developing a two empirical strategy model, in one specification they used firm year fixed effects to control for time varying firm specific characteristics, while in the other, they model selection with the two step Heckman procedure using the 
augmented gravity model variables as exclusion restrictions obtaining the same results.

[33] [34] also examined bilateral trade flows particularly for cases of zero bilateral trade using a sample selection gravity trade model specification. This involved specifying a sample selection model that takes into account the censoring process that leads to zero bilateral trade flows. Similar papers such as [35], also estimated bilateral trade flows and trade volumes using Tobit estimator to examine bilateral zeros.

This study examines trade flows by considering exports across regions. The method of identification of the trade model is one in which exporters belief will shaped by institutions in destination countries allowing for the inclusion of institutions in the trade model to be estimated. Trade in regions will now be assumed to depend on a host of factors that we identify affect trade across regions these include access to domestic and international markets, tariffs, market size, flow of foreign direct investment, fluctuation in the global economy, and institutions which represent as change in environment. Changes in trade with respect to institutions over time will now be a function of three increasing functions which include market size $\left(M_{K} \geq 0\right)$, exchange rate $\left(E X G_{K} \geq 0\right)$ and tariffs $\left(T_{K} \geq 0\right)$ and two decreasing function foreign direct investment $\left(F D I_{K} \leq 0\right)$ and access to market $\left(A_{K} \leq 0\right)$ where $\mathrm{k}$ is the index for countries can be written below as.

$$
\frac{\text { dExports }_{K}}{{\mathrm{~d} I N S T_{K}}}=\frac{M_{K}, E X G_{K}, T_{K}}{F D I_{K}, A_{K}}
$$

Trade (expressed as $\log$ Exports $_{i, t}$ ) taking the logarithm of exports due to the noisiness of exports, can be expressed as a function of institutions which is defined as the change in environment $I N S T_{K}$ which will also be true since institutions will depict the business environment and a set of exogenous variables, $X_{i, t}^{\prime}$ which include access to market $A_{K}$ market size $M_{K}$, foreign direct investment inflow $F D I_{K}$, fluctuations in the global economy that affect trade $E X G_{K}$ and tariffs $T_{K}$ which can be written as $f\left(I N S T_{K}, A_{K}, M_{K}, F D I_{K}, E X G_{K}, T_{K}\right)$. Allowing for the expression of the trade equation to be estimated below as one in which trade ( $\left.\log _{\text {Exports }}, t\right)$ depends on exporters belief captured by institutions ( inst $_{i, t}$ ) in exporting and destination countries and other exogenous effects $X_{i, t}$. This can now be written as shown below in Equation (6). The variable year is also included to capture regional fixed effects and account for differences in exporting in years across regions.

$$
\log _{\text {Exports }_{i, t}}=\left(\alpha_{0}-1\right) \log _{\text {Exports }},{ }_{i, t-1}+\alpha_{1} I_{N S T}{ }_{i, t}+\alpha_{2} X_{i, t}^{\prime}+\epsilon_{i, t}
$$

The method of estimation used is the general method of moment (GMM) estimation technique. The GMM estimator allows us to handle modeling concerns such as fixed effects that are likely to affect exports and the presence of endogenous regressors; thus allowing us to resolve the issues of endogeneity of the institutional variable while avoiding panel bias. It also handles unbalanced panel and multiple endogenous regressor [36]-[38].

The GMM also has some obvious advantages some include the fact that, it is not restricted by choice of functional form and it overcomes issues of endogeneity by using all explanatory variables as instruments and the estimates are robust even in the presence of heteroscedatic errors. The system GMM fit the one dependent variable $\log _{E^{2}}$ ports $_{i, t}$, model using linear GMM as shown above in Equation (6), where $i$ represent indexes for regions, and $t$ is the index for time. The vector of explanatory variables is given by $X_{i, t}^{\prime}$ and $\left(\alpha_{0}-1\right)$ is the lagged value of the dependent variable. The disturbance term $\epsilon_{i, t}$ has two orthogonal components the fixed effects $\mu_{i, t}$ and the idiosyncratic shocks $v_{i, t}$ see [38] for extensive explanation of the GMM estimator.

\section{Data, Empirical Analysis and Results}

\subsection{Data and Sources}

Panel data from seven regions (Africa, North America, Latin America, Australia, European Union, South East Asia Pacific the Middle East) were used for a period of 1980 to 2010, representing 31 years. All data are obtained from World development indicator (WDI) database unless otherwise stated. The dependent is exports in constant US dollars. The log of exports was taken due to the noisy nature of exports. Exports are a measure of total exports of goods and services from countries in regions. Other explanatory variables include the various measures institutions, these include infrastructural measures (number of telephone lines), judicial measures (strength of legal rights) and civil administrative measures (time to execute contract in no of days) these were used as measures for domestic institutions, also two measures for international institutions were used these were multilateral official development assistance (ODA) that captures aid agencies specific aid disbursement policy 
particularly to trade and other economic policy conditionality, and the dummy for signatory of world trade organization membership, which measure the influence of the world trade organization on regional specific trade institutions. These measures were also used to construct an index for both domestic and international institutions respectively using principal component analysis, respectively see [8] [10] and Schlens [9], for further discussions on index construction. Other data such as Exchange rate in constant USD, market size measured using GDP per capita, access to credit facilities measured using regional specific aggregate commercial bank lending in constant USD and transaction cost of transporting goods and services to both local and foreign markets (captured using crude oil price) multiplied by regional size in square kilometers were also obtained (Table 2).

\subsection{Empirical Analysis}

The intuition for the study is one that tries to portray a situation where institutions provide the adequate enabling environment for trade. Exporters or producers are likely to develop strong ties with distributors and buyers in importing countries due to good enabling environment. This is likely to lead to an increase in exports making institutions to have the potentials of promoting trade. We find no reason to dispute this fundamental intuition since countries that have poor institutions are likely to have very few international trade ties.

The trade equation is estimated using the GMM estimation method. This also allows us to control for the presence of endogenous regressors in our model specification as stated earlier, in addition the dynamic panel GMM model controls for long run effects making their estimates to be more reliable. The Arellano-Bond mis-specification test for auto-correlation was run and the null hypothesis indicating the absence of auto correlated errors in the underlying levels variables in the regression estimates was accepted, see [39] for further discussion on auto correlated errors in underlying levels variables of regression estimates. We also test the over-identification restriction since the system GMM uses all explanatory variables and the lagged values of the explanatory variables as instruments, implying that we have more instruments than explanatory variables, and accept the null hypothesis that the regression residuals are not correlated with the set of exogenous variables allowing us to state that the instruments are strictly exogenous see [40]-[42] for further discussion. All mis-specification test results are presented in Table 3.

Table 2. List of variables and description.

\begin{tabular}{|c|c|c|c|}
\hline \multirow[b]{2}{*}{ Variables } & \multicolumn{3}{|r|}{ Table Column Head } \\
\hline & Sources & Abbreviations & Description \\
\hline $\begin{array}{l}\text { Legal right strength } \\
\text { (measure of domestic institutions) }\end{array}$ & World Bank data & & $\begin{array}{l}\text { Measured using percentage of cases concluded } \\
\text { in courts per year. }\end{array}$ \\
\hline $\begin{array}{l}\text { No. of phone lines } \\
\text { (measure of domestic institutions) }\end{array}$ & World Bank data & & $\begin{array}{l}\text { Total annual aggregate of the number of phone } \\
\text { lines in use in regions. }\end{array}$ \\
\hline Domestic institutions index & Authors & D. Inst. & $\begin{array}{l}\text { Constructed by author using principa } \\
\text { component analysis. }\end{array}$ \\
\hline $\begin{array}{l}\text { World Trade Organization dummy } \\
\text { (measure of international institutions) }\end{array}$ & Authors & WTO dummy & $\begin{array}{l}\text { Dummy for membership and participation in } \\
\text { World Trade Organization. }\end{array}$ \\
\hline $\begin{array}{l}\text { Multilateral Aid (measure of } \\
\text { international institutions) }\end{array}$ & World Bank data & & $\begin{array}{l}\text { Inflow of multilateral development assistance } \\
\text { in USD to capabilities that can facilitate trade. }\end{array}$ \\
\hline International institutions index & Authors & I. Inst. & $\begin{array}{l}\text { Constructed by author using principal } \\
\text { component analysis }\end{array}$ \\
\hline Exchange rate & World Bank data & & Average local currency dollar exchange rates. \\
\hline Foreign direct investment & World Bank data & FDI & $\begin{array}{l}\text { Inflow of foreign direct investment to countries } \\
\text { in regions in USD. }\end{array}$ \\
\hline Market Access & World Bank data & Marketacc & $\begin{array}{l}\text { Cost of transportation to local and foreign markets } \\
\text { captured using crude price multiplied by regional size. }\end{array}$ \\
\hline Market size & World Bank data & $\begin{array}{l}\text { Marketsize } \\
\text { (gdppercap) }\end{array}$ & $\begin{array}{l}\text { Market size was captured using regional GDP per } \\
\text { capital strength in USD. }\end{array}$ \\
\hline Average tariffs & World Bank data & Avetariffs & $\begin{array}{l}\text { This was regional average tariffs on imported } \\
\text { commodities in regions. }\end{array}$ \\
\hline
\end{tabular}

Note: All data are obtained from World Bank world development indicator (WDI) data and constructed indexes are obtained from values of their WDI component measures unless otherwise stated. The abbreviation USD represents United States Dollars. 


\subsection{Results}

The results of the exports regressions are presented below in Table 3 it shows that our measures of domestic institution (legal right strength and number of phone lines) are weakly significant in promoting exports across regions. The index for domestic institution created from the legal right strength and number of phone lines also had a weak significant effect on exports. The dummy for WTO membership had a weak significant effect on exports while the flow of multilateral aid had no significant effect on exporting. The index for international institutions created also from both measures of international institutions (inflow of official aid and WTO signatory and participation) had a weak significant effect on regional exports.

The implication of our results is that institutions were in general having a significant effect on exports in regions although this effect was weak. The results of the interactive variables where institutions were interacted with market size, market access and average tariffs show, that international institutions were promoting market size, facilitating access to foreign markets and reducing tariffs across regions, while domestic institutions were not improving any of these factors see Table A1 in the appendix for the results. As a check for robustness of the institutional measures using regression component residuals measures, alternative measure of domestic and international institutions such as time to execute contracts and United Nations voting patterns were used the findings were the same even after inserting squares and cubes of tariffs as controls the results are excluded for the sake of brevity.

Table 3. System GMM results of the impact of institutions on trade.

\begin{tabular}{|c|c|c|c|c|c|c|}
\hline \multirow{3}{*}{$\begin{array}{c}\text { Table Head } \\
\text { Variables }\end{array}$} & \multicolumn{6}{|c|}{ Table Column Head } \\
\hline & (1) & (2) & (3) & (4) & (5) & (6) \\
\hline & Log of exports & Log of exports & Log of exports & Log of exports & Log of exports & Log of exports \\
\hline \multirow[t]{2}{*}{ Legal right strength } & $2.23^{*}$ & & & & & \\
\hline & (1.33) & & & & & \\
\hline \multirow[t]{2}{*}{ No of Phone lines } & & $0.92^{*}$ & & & & \\
\hline & & $(0.48)$ & & & & \\
\hline \multirow[t]{2}{*}{ Domestic institutions } & & & $4.21^{*}$ & & & \\
\hline & & & $(2.50)$ & & & \\
\hline \multirow[t]{2}{*}{ WTO dummy } & & & & $11.45^{*}$ & & \\
\hline & & & & $(6.78)$ & & \\
\hline \multirow[t]{2}{*}{ Multilateral Aid } & & & & & 0.0002 & \\
\hline & & & & & $(0.0001)$ & \\
\hline \multirow[t]{2}{*}{ International institutions } & & & & & & $1.75^{*}$ \\
\hline & & & & & & $(1.04)$ \\
\hline \multirow[t]{2}{*}{ Exchange rate } & 0.01 & $0.01^{*}$ & 0.01 & $0.09^{*}$ & 0.02 & $0.03^{*}$ \\
\hline & $(0.01)$ & $(0.01)$ & $(0.01)$ & $(0.05)$ & $(0.01)$ & $(0.02)$ \\
\hline \multirow[t]{2}{*}{ FDI } & 0.01 & 0.01 & 0.01 & 0.01 & 0.01 & -0.01 \\
\hline & $(0.01)$ & $(0.01)$ & $(0.01)$ & $(0.01)$ & $(0.01)$ & $(0.01)$ \\
\hline \multirow[t]{2}{*}{ Market Access } & -0.31 & $0.33^{* *}$ & -0.23 & $-0.03^{*}$ & -0.04 & $-0.95^{*}$ \\
\hline & $(0.37)$ & $(0.14)$ & $(0.36)$ & $(0.16)$ & $(0.37)$ & $(0.56)$ \\
\hline \multirow[t]{2}{*}{ Market size } & 0.33 & $-0.01^{*}$ & 0.35 & $1.54^{*}$ & $0.40^{*}$ & $0.71^{* *}$ \\
\hline & $(0.22)$ & $(0.01)$ & $(0.22)$ & $(0.79)$ & $(0.22)$ & $(0.34)$ \\
\hline \multirow[t]{2}{*}{ Average tariffs } & -0.67 & $4.14^{* *}$ & $1.671^{* *}$ & -0.387 & $1.928^{* *}$ & $2.746^{* *}$ \\
\hline & $(1.02)$ & $(1.68)$ & $(0.74)$ & $(0.91)$ & $(0.87)$ & $(1.10)$ \\
\hline A-B (ar2) test (p-value) & 0.65 & 0.24 & 0.62 & 0.73 & 0.49 & 0.83 \\
\hline Sargan Test (p-value) & 1.00 & 1.00 & 1.00 & 1.00 & 1.00 & 1.00 \\
\hline Observations & 210 & 210 & 210 & 210 & 210 & 210 \\
\hline
\end{tabular}

Standard errors in parentheses ${ }^{* * *} \mathrm{p}<0.01,{ }^{* *} \mathrm{p}<0.05,{ }^{*} \mathrm{p}<0.1$. Note: The system GMM arrelano-bond (AB) and Sargan-Hansen mis-specification tests for autocorrelation and over-identifying restrictions are presented in the table above, however the null hypothesis is accepted at p-values higher than 0.05 as explained in the paper by Roodman (2009), which states that accepting the null hypothesis at lower significance level is likely to lead to bias, of the regression estimates. 


\section{Discussion and Conclusion}

\subsection{Discussion}

Institutions were generally found to exert some significant effect on trade across regions. Domestic institutions such as infrastructural measures which reflect regional implementation of social policy through institutions as well as judicial strength in the enforcement of legal rights had significant effect on trade.

International institutions also had some significant effect on trade although the inflow of aid to capabilities that can boost trade were not effective in trade promotion, the effect of this factor is not expected to be immediate since returns from trade capacity building is likely to affect trade from past periods therefore using the lagged values of aid inflow would probably have been more beneficial in this case which is a limitation of the study. However, countries implementation of world trade organization trade policies and membership of the world trade organization was useful in promoting trade across regions.

Domestic institutions were probably protectionist in nature since they were not boosting regional market development (exerting no effect on market size through its interactive presence), not reducing tariffs and was having no effect on reducing transaction cost associated with trade. International institutions were found to improve regional market size, reduce tariffs and facilitate access to regional markets in general making international institutions to be most relevant to trade across regions allowing us to proffer answers to the objectives of the study.

a) Institutions were found to matter in the promotion of international trade in exports across regions since they were exerting significant effect on trade by significantly promoting exports across regions.

b) International institutions were more effective in improving access to destination markets through transaction cost reduction see results in Table A1.

c) International institutions were also found to develop regional markets see interactive variable results in Table A1 where the variable international institutions*market size was exerting a significant effect on trade.

d) Domestic institutions were found to be more protectionists since it did not promote tariff that can increase exports across regions and were probably protecting domestic firms from foreign competitors, international institutions were probably more concerned about tariff reduction and facilitating trade across regions in general.

\subsection{Conclusions}

In the concluding section we summarize all the major findings in the study. The question posed at the beginning of the study, if institutions matter in the trade promotion nexus, are clearly answered by the findings. It was found that institutions were probably significantly affecting exports across regions from the results. The results of institutional quality effectiveness (i.e. the interactive variable) in promoting exports, show that although international institutions were probably improving market size through developing regional market potential, domestic institutions were not, also domestic institutions also had no effect on tariffs reduction across regions, while international institutions were also found to be promoting regional integration through tariffs reduction in regions, depicting again that institutions matter, in the export promotion equation.

The question if institutions were effective in reducing the transaction cost associated with trade, through the development of regional markets and facilitation of access to local and foreign markets was also answered, since international institutions were facilitating all three factors however, domestic institutions were found not to. They were probably increasing tariffs and protecting domestic businesses from hostile competition associated with international trade by driving up the final cost of imported goods.

The policy implication of this paper is that adequate attention should be paid to domestic institutions with the aim of finding ways through which they can facilitate international trade through market development strategies, tariffs reduction, reduction of transaction cost associated with exports through infrastructural development and reduction in bureaucracy surrounding export document processing at ports and transparency in the exports and imports regulation process to make international trade less cumbersome for exporters and importers.

Finally this paper also contributes to the body of knowledge through offering an insight on the difference of domestic institution effect on trade from those of international institutions thereby examining if there are differences in their contribution to the regional trade promotion process to which this paper concludes exists.

\section{References}

[1] United Nations Statistics, 2010. http://unstats.un.org/unsd/tradekb/Default.aspx 
[2] World Trade Organization, Statistics, 2011. http://www.wto.org/english/res_e/statis_e/its2011_e/its2011_e.pdf

[3] OECD Statistics, 2012. http://www.oecd-ilibrary.org/taxation/revenue-statistics-2012 rev stats-2012-en-fr

[4] UNCTARD Handbook of Statistics, 2012. http://unctad.org/en/pages/PublicationWebflyer.aspx?publicationid=381

[5] UN Statistics, 2012. www.unstats.un.org/unsd/statcom/sc2012.htm

[6] World Bank Statistics, 2012. http://data.worldbank.org/data-catalog/world-development-indicators/wdi-2012

[7] UNESCO (2006) Strong Foundations: Early Childhood Care and Education. EFA (Education for All) Global Monitoring Report, 2007. UNESCO, Paris.

[8] Abeyasekera S. (2004) Multivariate Methods for Index Construction Statistical Services Centre University of Reading Reading, United Kingdom of Great Britain and Northern Ireland. http://unstats.un.org/unsd/hhsurveys/pdf/Chapter 18.pdf

[9] Schlens, J. (2005) A Tutorial on Principal Component Analysis Institute for Nonlinear Science, University of California, San Diego La Jolla, CA 92093-0402.

[10] Burnside, C. and Dollar, D. (2000) Aid Policies and Growth American Economic Review.

[11] Mauro, P. (1995) Corruption and Growth. The Quarterly Journal of Economics, MIT Press, 110, 681-712. http://dx.doi.org/10.2307/2946696

[12] Keefer, P. and Knack, S. (1995) Institutions and Economic Performance: Cross-Country Tests Using Alternative Institutional Measures. Economics and Politics, 7, 207-227.

[13] Hall, R.E. and Jones, C.I. (1999) Why Do Some Countries Produce So Much More Output per Worker than Others? Quarterly Journal of Economics, 114, 83-116. http://dx.doi.org/10.1162/003355399555954

[14] Olson, M. (2003) Big Bills Left on the Sidewalk: Why Some Nations are Rich and, and Others Poor. In: Knack, S., Ed., Democracy, Governance and Growth, The University of Michigan Press, Ann Arbor.

[15] Acemoglu, D., Johnson, S. and Robinson, J. (2001) The Colonial Origins of Comparative Development: An Empirical Investigation. American Economic Review, 91, 1369-1401. http://dx.doi.org/10.1257/aer.91.5.1369

[16] Weiss, T. (2000) Governance, Good Governance and Global Governance: Conceptual and Actual Challenges. Third World Quarterly, 21, 795-814. http://dx.doi.org/10.1080/713701075

[17] Anderson, L. (2001) The Implications of Institutional Design for Macroeconomic Performance: Reassessing the Claims of Consensus Democracy. Comparative Political Studies, 34, 429-452.

[18] Dollar, D. and Kraay, A. (2002) Institutions, Trade, and Growth. Journal of Monetary Economics, 50, 133-162. http://dx.doi.org/10.1016/S0304-3932(02)00206-4

[19] Wacziary, R. and Welch, K.H. (2003) Trade Liberalization and Growth: New Evidence. Economic Review, 22, 187231.

[20] Rodrik, D., Subramanian, A. and Trebbi, F. (2004) Institutions Rule: The Primacy of Institutions, Geography and Integration in Economic Development. Journal of Economic Growth, 9, 131-165. http://dx.doi.org/10.1023/B:JOEG.0000031425.72248.85

[21] Freund, C. and Bolaky, B. (2004) Trade, Regulations and Growth. IMF Conference on Trade and Growth Research Department, Washington DC, 9 January 2006.

[22] Chang, R., Kaltani, L. and Loayza, N. (2005) Openness Can Be Good for Growth: The Role of Policy Complementarities. World Bank Policy Research Working Paper No. 3763.

[23] Depken II, C.A. and R.J. Sonora (2005) Asymmetric Effects of Economic Freedom on International Trade Flows. International Journal of Business and Economics, 4, 141-155.

[24] Trade Development Report, 2003.

[25] UNCTARD Report, 2013.

[26] Bigsten, A., Collier, P., Dercon, S., Fafchamps, M., Gauthier, B., Gunning, J.W., Isaksson, A., Oduro, A., Oostendorp, R., Pattillo, C., Söderbom, M., Teal, F., Zeufack, A. and Appleton, S. (2000) Rates of Return on Physical and Human Capital in Africa's Manufacturing Sector. Economic Development and Cultural Change, Forthcoming.

[27] Anderson, J.E and Marcouiller, D. (2002) Insecurity and the Pattern of Trade: An Empirical Investigation. Review of NBER working paper.

[28] Anderson, J.E. and Marcouiller D. (2002) Insecurity and the Pattern of Trade: An Empirical Investigation. Review of NBER Working Paper.

[29] Paul, O. (2014) Does Foreign Aid Promote Trade? Evidence from Some Selected African Countries. European Journal of Contemporary Economics, Lisbon, Portugal May 2014. www.http://ejcem.eu/images/EDITIONS/Vol.1/No.1/2.pdf. 
[30] Ojeaga, P. (2014) Does Foreign Aid Promote Trade? Evidence from Some Selected African Countries European Journal of Contemporary Economics Lisbon Portugal May 2014. www.http://ejcem.eu/images/EDITIONS/Vol.1/No.1/2.pdf

[31] Araujo, L. and Ornelas, E. (2007) Trust-Based Trade. CEP Discussion Paper.

[32] Araujo, L.F., Mion, G. and Ornelas, E. (2012) Institutions and Export Dynamics, Technical Report. London School of Economics Working Paper.

[33] Francois, J.F. and Manchin, M. (2007) Institutions, Infrastructure and Trade. Centro Studi Luca d'Agliano Development Studies Working Paper No. 224.

[34] Francois, J.F., Miriam, M. and Martin, W. (2012) Market Structure in CGE Model of International Trade. In: Dixon, P. and Jorgenson, D., Eds., Handbook of Computable General Equilibrium Modeling, Elsevier, Amsterdam.

[35] Felbermayr, G.J. and Kohler, W. (2004) Exploring the Intensive and Extensive Margins of World Trade. CESifo Working Papers.

[36] Arellano, B. (1998) Dynamic Panel Data Estimation USING DPD98 for Gauss: A Guide for Users.

[37] Doornik, J.A., Arellano, M. and Bond, S. (2002) Panel Data Estimation Using DPD for Ox.

[38] Roodman, D. (2009) A Note on the Theme of Too Many Instruments. Oxford Bulletin of Economics Statistics, 71, 135-158.

[39] Arellano, M. and Bond, S. (1991) Some Tests of Specification for Panel Data: Monte Carlo Evidence and an Application to Employment Equations. Review of Economic Studies, 58, 277-297.

[40] Sargan, J. (1958) The Estimation of Economic Relationships Using Instrumental Variables. Econometrica, 26, $393-415$. http://dx.doi.org/10.2307/1907619

[41] Hansen, L. (1982) Large Sample Properties of Generalized Method of Moments Estimators. Econometrica, 50, 10291054. http://dx.doi.org/10.2307/1912775

[42] Bowsher, C.G. (2002) On Testing Overidentifying Restrictions in Dynamic Panel Data Models. Economics Letters, 77, 211-220. http://dx.doi.org/10.1016/S0165-1765(02)00130-1 


\section{Appendix 1}

Table A1. Regression of the impact of institutions on trade including the interactive variables.

\begin{tabular}{|c|c|c|c|c|c|c|}
\hline \multirow{3}{*}{$\begin{array}{l}\text { Table Head } \\
\text { Variables }\end{array}$} & \multicolumn{6}{|c|}{ Table Column Head } \\
\hline & (1) & (2) & (3) & (4) & (5) & (6) \\
\hline & Log of exports & Log of exports & Log of exports & Log of exports & Log of exports & Log of exports \\
\hline \multirow[t]{2}{*}{ L.lnexports } & 0.0959 & 0.411 & -0.574 & -0.784 & -0.757 & $2.674^{* * *}$ \\
\hline & $(0.551)$ & (1.053) & (1.204) & $(0.793)$ & (0.685) & $(0.799)$ \\
\hline \multirow[t]{2}{*}{ Legal rights strength } & 1.814 & & & & & \\
\hline & (3.732) & & & & & \\
\hline \multirow[t]{2}{*}{ No. of Phone lines } & & 0.136 & & & & \\
\hline & & $(0.282)$ & & & & \\
\hline \multirow[t]{2}{*}{ D. Inst. } & & & 9.256 & & & \\
\hline & & & (19.25) & & & \\
\hline \multirow[t]{2}{*}{ Wto_dummy } & & & & 4.984 & & \\
\hline & & & & (5.038) & & \\
\hline \multirow[t]{2}{*}{ Multilateral aid } & & & & & 0.000116 & \\
\hline & & & & & $(0.00023)$ & \\
\hline \multirow[t]{2}{*}{ I. inst. } & & & & & & $28.89^{* *}$ \\
\hline & & & & & & (13.32) \\
\hline \multirow[t]{2}{*}{ Exchange rate } & 0.0008 & -0.00141 & 0.00536 & $0.0225^{*}$ & 0.00446 & $-0.0400^{* *}$ \\
\hline & $(0.003)$ & $(0.006)$ & $(0.009)$ & $(0.012)$ & -0.00402 & -0.0162 \\
\hline \multirow[t]{2}{*}{ FDI } & 0.01 & $0.01^{*}$ & 0.01 & $0.01^{* *}$ & 0.01 & $0.01^{* * *}$ \\
\hline & $(0.01)$ & $(0.02)$ & $(0.01)$ & $(0.01)$ & $(0.01)$ & $(0.01)$ \\
\hline \multirow[t]{2}{*}{ D.Inst ${ }^{*}$ markaccess } & -7.87 & -6.18 & -2.12 & & & \\
\hline & (1.33) & (1.09) & (3.88) & & & \\
\hline \multirow[t]{2}{*}{ D.Inst ${ }^{*}$ marksize } & 0.0012 & 0.005 & 0.005 & & & \\
\hline & $(0.002)$ & $(0.007)$ & $(0.0142)$ & & & \\
\hline \multirow[t]{2}{*}{ D.Inst ${ }^{*}$ avetariff } & 0.202 & $0.564^{*}$ & -0.257 & & & \\
\hline & $(0.599)$ & $(0.308)$ & (1.531) & & & \\
\hline \multirow[t]{2}{*}{ I.inst. ${ }^{*}$ markacc } & & & & $5.10^{* *}$ & $1.25^{*}$ & $13.00^{* *}$ \\
\hline & & & & $(2.36)$ & $(7.02)$ & $(5.20)$ \\
\hline \multirow[t]{2}{*}{ I.inst. ${ }^{*}$ marksize } & & & & $-0.736^{*}$ & 0.00944 & $0.456^{* *}$ \\
\hline & & & & $(0.38)$ & $(0.0226)$ & $(0.198)$ \\
\hline \multirow[t]{2}{*}{ I.inst."avetariff } & & & & $0.307^{*}$ & -0.0284 & $1.928^{* *}$ \\
\hline & & & & $(0.161)$ & $(0.118)$ & $(0.968)$ \\
\hline $\mathrm{AB}(\mathrm{ar} 2)$ test(p-value) & 0.63 & 0.22 & 0.64 & 0.75 & 0.59 & 0.85 \\
\hline Sargan Test (p-value) & 1.00 & 1.00 & 1.00 & 1.00 & 1.00 & 1.00 \\
\hline Observations & 210 & 210 & 210 & 210 & 210 & 210 \\
\hline
\end{tabular}

Standard errors in parentheses ${ }^{* * *} \mathrm{p}<0.01,{ }^{* *} \mathrm{p}<0.05,{ }^{*} \mathrm{p}<0.1$ Note: The regression where the interactive were included is presented above the abbreviations for domestic and international institutions are D.Inst. and I.Inst. and those for average tariffs, market access and market size are avetariff, markacc and marksize respectively. 
Scientific Research Publishing (SCIRP) is one of the largest Open Access journal publishers. It is currently publishing more than 200 open access, online, peer-reviewed journals covering a wide range of academic disciplines. SCIRP serves the worldwide academic communities and contributes to the progress and application of science with its publication.

Other selected journals from SCIRP are listed as below. Submit your manuscript to us via either submit@scirp.org or Online Submission Portal.
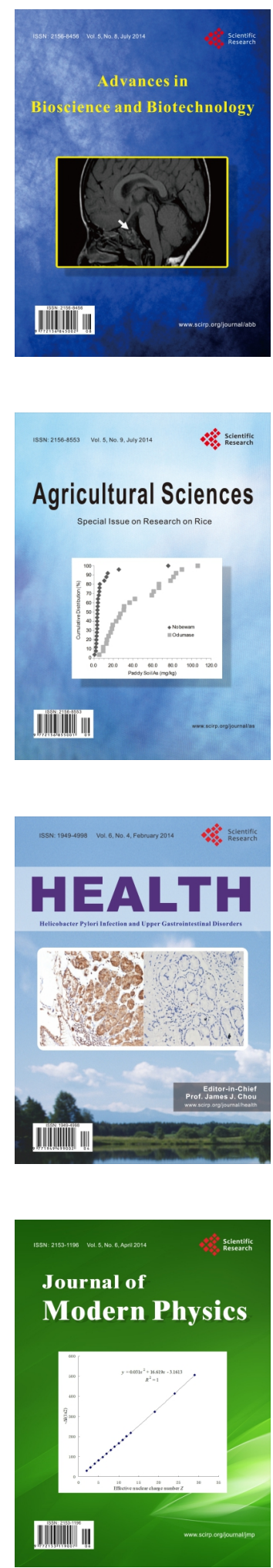
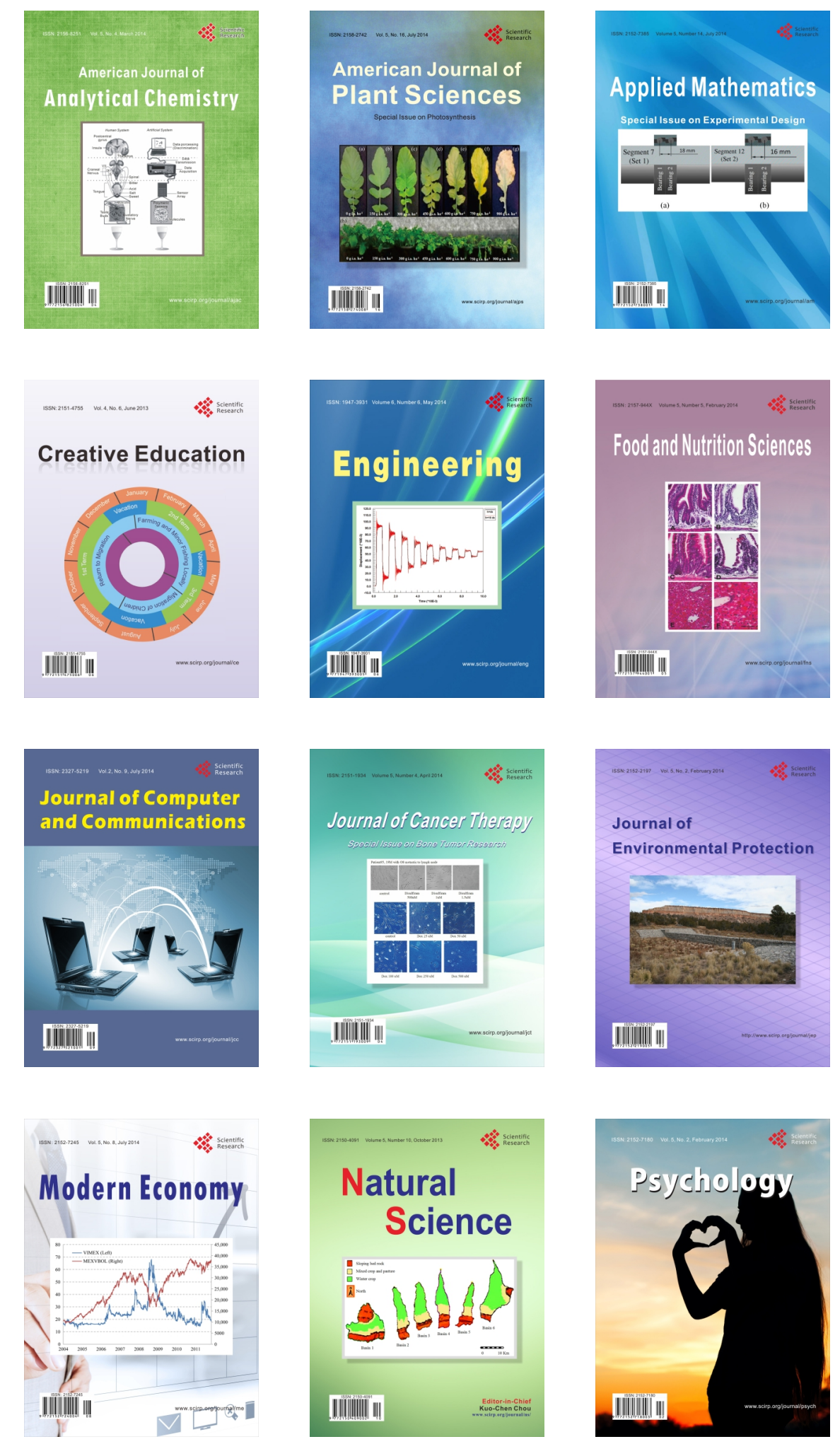